\title{
PROTIDES OF THE BIOLOGICAL FLUIDS
}

PROCEEDINGS OF THE TWENTY-NINTH COLLOQUIUM, 1981

Edited by

\section{H. PEETERS}

Director

Institute for Medical Biology

Brussels, Belgium 
U.K.

U.S.A.

CANADA

AUSTRALIA

FRANCE

FEDERAL REPUBLIC OF GERMANY
Pergamon Press Ltd., Headington Hill Hall, Oxford OX3 OBW, England

Pergamon Press Inc., Maxwell House, Fairview Park, Elmsford, New York 10523, U.S.A.

Pergamon Press Canada Lıd., Suite 104,

150 Consumers Rd., Willowdale, Ontario M2J 1P9, Canada

Pergamon Press (Aust.) Pty. Ltd., P.O. Box 544,

Potts Point, N.S.W. 2011, Australia

Pergamon Press SARL, 24 rue des Ecoles,

75240 Paris, Cedex 05, France

Pergamon Press GmbH, 6242 Kronberg-Taunus,

Hammerweg 6, Federal Republic of Germany

Copyright (C) 1982 Pergamon Press L.td.

All Rights Reserved. No part of this publication may be reproduced, stored in a retrieval system or transmitted in any form or by any means: electronic, electrostatic, magnetic tape, mechanical, photocopying, recording or otherwise, without permission in writing from the publishers.

\section{Library of Congress Catalog Card No. 58-5908}

In order to make this volume available as economically and as rapidly as possible the authors' typescripts have been reproduced in their original forms. This method unfortunately has its typographical limitations but it is hoped that they in no way distract the reader.

Bayerische

Staatsbibliothek

München

Printed in Great Britain by A. Wheaton \& Co. Ltd., Exeter

ISBN 0080279880

ISSN 0079-7065 


\section{CONTENTS}

PREFACE $\quad x x v$

ACKNOWLEDGEMENTS Xxvii

THE TENTH ARNE TISELIUS MEMORIAL

LECTURE

H-Y Antigen and Sex Determination

HARTWIG CLEVE

\section{SECTION A. MEMBRANE PROTEINS}

\section{A.1. Pure Membrane Proteins}

\section{A.1.1. Purification Procedures}

Some General Aspects of the Difficulties to Purify Membrane Proteins

S. HJERTÉN, H. PAN and K. YAO

New Application of Group-Specific Reagents for Hydrophobic Labeling and

Crosslinking of Membrane Proteins

H. SIGRIST, P. R. ALLEGRINI, A. HALDEMANN and P. ZAHLER

The Use of a Zwitterionic Detergent and a Monoclonal Antibody in Purification of Rat Liver 5'-Nucleotidase

J. P. LUZIO, E. M. BAILYES, A. C. NEWBY and K. SIDDLE 


\section{A.1.2. Immunoglobulins}

Human IgD, The Gene and the Protein

T. H. RABBITTS and C. P. MILSTEIN

Structural Studies of Human IgD

B. DEBUIRE and F. W. PUTMAN

Comparison of Secreted and Membrane-Bound Human Immunoglobulins M and D

R. K. L. BIJLENGA, H. P. KOCHER and J.-C. JATON

\section{A.1.3. Glycoproteins}

The Sialoglycoproteins (Glycophorins) in the Plasma Membranes of Different

Cells and Their Receptor Functions

H. FURTHMAYR

Structures and Antigenic Properties of Human Erythrocyte Membrane

Sialoglycoproteins

W. DAHR, K. BEYREUTHER, E. BAUSE and M. KORDOWICZ

Cytoskeleton-Associated Surface Glycoproteins of Murine Lymphocytes

E. RUNGGER-BRÄNDLE and D. C. HOESSLI

The Relationship between Differentiation of Friend Erythroleukemia Cells and

Synthesis of Plasma Membrane-Bound Glycoproteins

G. J. C. M. BOSMAN, P. BOER and E. P. STEYN-PARVÉ

Variations in the Structure of Surface Glycoproteins Present in Different

Lymphocyte Subpopulations

D. HOESSLI, J. R. L. PINK, R. HOOGHE, M. SCHREIER and P. VASSALLI

Enhanced Neuraminidase-Resistant Sialic Acid Content in the Surface

Glycopeptides of Human Leukaemic Hairy Cells

G. A. J. M. VAN DER HOFSTAD and M. E. VAN RYMENANT

Reconstitution of Liposomes Bearing Platelet Membrane Glycoproteins.

A Functional Study with Von Willebrand Factor

P. SIE, M. GILLOIS, H. J. CHAP, B. BONEU, R. BIERMÉ and

L. DOUSTE-BLAZY

Human Platelet Membrane Glycoproteins IIb and IIIa May form

$\mathrm{Ca}^{2+}$-Dependent Complexes

D. PIDARD, T. KUNICKI, J.-P. ROSA and A. T. NURDEN

Glycoproteins of the Human Syncytiotrophoblastic Plasma Membrane

M. J. O'SUllivan, J. A. McINTYRE, G. A. WARRINER and

W. PAGE FAULK 
Characterization of $\alpha$-Tissue Antigen ( $\alpha \mathrm{TA}$ ), A Membrane Glycoprotein of Cancer Cells

A. YACHI, M. KAWAHARADA, Y. AKAHONAI, K. IMAI and T. WADA

The Structure and Function of a Membrane Glycoprotein Encoded in the Adenovirus Genome

HÅKAN PERSSON and LENNART PHILIPSON

Protein Micelles and Virosomes from the Surface Glycoproteins of Parainfluenza 3 Virus

B. MOREIN, B. SUNDQUIST, S. HÖGLUND, A. HELENIUS and K. SIMONS

\section{A.1.4. Erythrocyte Membrane Proteins}

Human Red Cell Membrane Acetylcholinesterase, A Model Enzyme for the Study of Protein-Amphiphile Interactions

U. BRODBECK and P. OTT

Spectrin Free Vesicles Obtained from Human Erythrocytes Without

ATP-Depletion

P. OTT and U. BRODBECK

Acylation of Integral Erythrocyte Membrane Proteins Resulting in a Soluble

Form of Band 3 Protein

FRANZ HERBST and VICTOR RUDLOFF

Self-Association of Band 3 Protein from Erythrocyte Membranes in Solutions of a Nonionic Detergent, Ammonyx-LO

GUNTER PAPPERT and DIETER SCHUBERT

Interactions of the Isolated Spectrin Polypeptides (Bands 1 and 2) with

Phospholipid Monolayers

DIETER SCHUBERT, FRANZ HERBST, HANNELORE MARIE and VICTOR RUDLOFF

Red Cell Membrane Changes in a Heinz Body Anaemia (Kale Anaemia)

R. H. SMITH, W. B. WATT, W. J. LAWSON and C.RICE-EVANS

Ozone-Induced Cross-Linking of Erythrocyte Membrane Proteins

H. VERWEIJ and J. VAN STEVENINCK

\section{A.1.5. Various Cell Membrane Proteins}

Membrane Proteins of Murine T Cell Clones

C. BRON, M. SCHMID, G. CORRADIN, A. GLASEBROOK, H. ENGERS,

C. HORWATH, J. C. CEROTTINI and H. MACDONALD 
Isolation and Characterization of Basal-lateral and Luminal Plasma-Membranes (PM) from the Proximal Tubule of Human Kidney

J. E. SCHERBERICH, R. KINNE, C. GAUHL, W. MONDORF and

W. SCHOEPPE

Further Immunochemical Studies of Tissue Polypeptide Antigen (TPA)

BO WIKLUND and BJÖRN LÜNING

Purification of Membrane 5'Nucleotidase Preparation and Properties of Anti-5'

Nucleotidase Serum

J. DORNAND, J. C. BONNAFOUS and J. C. MANI

Characterization of Four Chick Brain Synaptic Membrane Proteins

M. J. ALBECK and E. BOCK

Isolation of a Membrane Antigen from Electric Organ of Torpedo Californica

E. BOCK and A. C. v. GERSTENBERG

Characterization of Some Antigens Associated with the Membrane of Hampster Tumor Cells

A. DUTHU, I. ALEXANDROV, H. HADDADA, N. LE GOFFIC,

J. ZUINGHEDAU and CH. DE VAUX SAINT CYR

Non-Specific Binding of $(-)^{3} \mathrm{H}$-Dihydroalprenolol to Intact Human Lymphocytes and Lymphocyte Membranes

HERMAN MEURS, WILLEM VAN DEN BOGAARD, HENK F. KAUFFMAN and PIETER L. B. BRUYNZEEL

Characterization of (-) $\left({ }^{3} \mathrm{H}\right)$ Dihydroalprenolol Binding Sites on Intact Human Peripheral Blood Lymphocytes

P. L. B. BRUYNZEEL, W. VAN DEN BOGAARD, M. L. HAMELINK and J. A. M. RAAIJMAKERS

\section{A.1.6. Bacterial Membrane Proteins}

Structure and Function of a Pore-Forming Transmembrane Protein:

High Resolution Studies of a Bacterial Porin

J. P. ROSENBUSCH, R. M. GARAVITO, D. L. DORSET and A. ENGEL

Evidence for Protein-Lipid Interactions in Membranes of Acholeplasma Laidlawii

A. WIESLANDER, K.-E. JOHANSSON, C. JÄGERSTEN and

A. CHRISTIANSSON

Isolation of Surface Antigens from Schistosoma Mansoni Schistosomula

C. DISSOUS and A. CAPRON

Crossed Immunoelectrophoretic Analysis of the Purple Membrane of Halobacterium Halobium

H. WRÓBLEWSKI and G. BAFFET 


\section{A.2. Cell Surface Antigens}

\section{A.2.1. Beta 2 Microglobulin}

Beta-2-Microglobulin and its Association with Histocompatibility Antigens of the Mouse and Rabbit

T. J. KINDT, J. E. COLIGAN, F. T. GATES III, E. S. KIMBALL, W. L. MALOY and J. M. WILKINSON

Evolutionary Conservation of the Interaction between $\beta_{2}$-Microglobulin and $ß_{2}$-Microglobulin-Binding Molecules

L. LÖGDBERG, L. BJÖRCK and R. CIGÉN

Seminal Plasma Levels of Beta 2 -Microglobulin and CEA-Like Protein in Infertility J. LIZANA, P. ENEROTH, B. BYSTRÖM and M. BYGDEMAN

Stimulation of Human Monocyte Chemotaxis by Anti- $\beta_{2}-$ Microglobulin

T. P. CONWAY and M. D. POULIK

Exchange of $\beta_{2}$-Microglobulin in Histocompatibility Antigens by its Human Analogue

W. SCHMIDT, A. R. SANDERSON and H. FESTENSTEIN

Rat Serum Components with Affinity for Human 32 Microglobulin

C. VINCENT and J. P. REVILLARD

\section{A.2.2. Blood Group Antigens}

Human Blood Group M-, N-, T (Thomsen-Friedenreich)-, and Tn-Specific Lipidic Substances in Line-10 Hepatocarcinoma of Strain-2 Guinea Pigs

G. F. SPRINGER, J. L. CANTRELL, P. R. DESAI and H. TEGTMEYER

Further Evidence that Terminal B-Galactopyranosyl Groups are

Immunodeterminant in Blood Group N Specificity

G. F. SPRINGER and H. TEGTMEYER

\section{A.2.3. Histocompatibility Antigens}

Biosynthesis of HLA-A and -B Antigens

M. J. OWEN, A.-M. KISSONERGHIS and C. KINNON

Biochemical Characterisation of Leukaemia-Associated Cell Surface Antigens

R. A. NEWMAN, D. R. SUTHERLAND and M. F. GREAVES

Influence of Selective Absence of $\mathrm{H}-2 \mathrm{~K}^{\mathrm{K}}$ on Gross Virus Leukaemias In Vitro and the Implications for In Vivo Surveillance of Leukaemia

H. FESTENSTEIN, W. SCHMIDT, A. ALONZO and L. LEBEN 
Primary Structural Analyses of Murine Major Histocompatibility Antigens

J. E. COLIGAN, E. S. KIMBALL, T. J. KINDT, W. L. MALOY,

J. M. MARTINKO, R. NAIRN, S. G. NATHENSON, H. UEHARA

Characterization of DLA SD Antigens using Immunochemical Techniques

M. J. M. VAN DER FELTZ, J. A. G. M. VAN DER KORPUT,

M. J. GIPHART and D. L. WESTBROEK

Neuron-Specific Markers: A Critical Appraisal

E. L. HOOGHE-PETERS, A. W. SIADAK, C. BEREK and R. J. HOOGHE

Variations in the Antigenic Architecture of the Acholeplasma Laidlawii Cell

Membrane

KARL-ERIK JOHANSSON and CHRISTINA JÄGERSTEN

Interspecies Crossreactivities of Antisera Directed Against (Na,K)-ATPase

Subunits from Bufo Marinus

M. GIRARDET, D. GESER, K. GEERING and C. BRON

\section{A.3. Membrane Function}

\section{A.3.1. Transport Function}

Transport of Proteins into Mitochondria

HOWARD RIEZMAN, SUSAN GASSER, PETER BÖHNI, GÜNTHER DAUM, AKIRA OHASHI, JANE GIBSON and GOTTFRIED SCHATZ

The Stereospecific D-Glucose Transport Activity of Cholate Extracts from Human

Erythrocyte Membranes. Effects of Cholate, EDTA and Dithioerythritol

P. LUNDAHL, S. PHUTRAKUL, F. ACEVEDO and G. FRÖMAN

Side-Specific Transfer of Membrane-Bound Phospholipase $\mathrm{A}_{2}$ to Other Membranes by Fusion

P. ZAHLER and M. WOLF

Bile Acid Transport in Distal Ileum

F. W. M. DE ROOIJ, J. W. O. VAN DEN BERG,

E. P. BOSMAN-JACOBS and A. C. BLOMMESTEIJN

The Kinetics of Intramolecular Crosslinking of the Band 3 Protein by 4,4'

-Diisothiocyanato Dihydrostilbene-2,2'-Disulfonic Acid $\left(\mathrm{H}_{2} \mathrm{DIDS}\right)$

L. KAMPMANN, S. LEPKE and H. PASSOW

The Effect of Arginine Specific Reagents on Anion Transport Across Red Blood

Cells

LAILA ZAKI 
Does Ternary Complex Formation Control the State of the Cation Barrier in the Resealed Human Red Blood Cell Ghost?

PHILLIP G. WOOD

\section{A.3.2. Cell Adhesion}

Microfilaments and Fibronectin Fibers Involved in the Formation of Fibroblast's Focal Contacts

W. BIRCHMEIER

Cell Surface Glycoproteins and Fibronectin Mediated Cell Adhesion

G. TARONE, G. GALETTO and P. M. COMOGLIO

The Actin Network in Human Granulocytes at Different Stages of Phagocytosis in Granulopathies

Y. FROBERT

Expression of Fibronectin and Plasminogen Activator in Human Cell Hybrids L. LARIZZA, M. TENCHINI, A. MOTTURA, E. RAMPOLDI, M. COLOMBI and S. BARLATI

Role of Fibronectin Degradation Products on Cellular Transformation

S. BARLATI, G. DE PETRO, T. VARTIO and A. VAHERI

\section{A.3.3 Cell Growth}

Possible Role of the Plasma Membrane in Regulating Cell Growth Behaviour

K. BALLMER and M. M. BURGER

Infiltration of Lymphosarcoma Cells into hepatocyte Cultures: Inhibition by Univalent Antibodies Against Liver Plasma Membranes and Lymphosarcoma Cells

O. P. MIDDELKOOP, E. ROOS and I. V. VAN DE PAVERT

The Role of Components of the Outer Membrane of Gram-Negative Bacteria in the Serum-Bactericidal Effect

F. CLAS and M. LOOS

Receptor-Ligand Interaction Leading to Entry of Myxoviruses into Host Cells RICHARD T. C. HUANG and RUDOLF ROTT

\section{A.3.4. Cell Ageing}

Molecular Aging: A Termination Antigen Appears on Senescent Cells

M. M. B. KAY

$\mathrm{K}^{+}$Fluxes During $\mathrm{T}$ Lymphocyte Activation in Human Aging

B. KENNES, P. MOEST, F. RICKART, A. DE MULDER and P. NÈVE 
Age-Related Defect of Cytokine-Ca ${ }^{2+}$-cGMP Mediated Transmembrane Signal in

T Lymphocyte Activation

B. KENNES, I. DUMONT, P. PIRO and P. NÈVE

Supramolecular Assembly of Membrane Constituents During 'In Vitro'

Aging of Human Erythrocytes

A. BROVELLI, G. PALLAVICINI, G. AIROLDI and C. BALDUINI

Masking of RCA I Binding Sites by Hyaluronic Acid in Foetal Liver Cells

B. BERNARD, J. FONT, M. AUBERY, C. GUGUEN-GUILLOUZO

and A. GUILLOUZO

Parallel Increase of 3-0-Methylglucose Uptake and Cytochalasin B Binding in Chick Fibroblasts During Embryo Development

B. BERNARD and M. AUBERY

\section{SECTION B. RECEPTOR LIGAND INTERACTIONS}

\section{B.1. Structure Activity Relations}

The Acetylcholine Receptor: An Allosteric Membrane Protein

R. E. OSWALD, T. HEIDMANN and J. P. CHANGEUX

Structure and Function of the Human Platelet Von Willebrand Factor Receptor K. J. CLEMETSON, H. Y. NAIM and E. F. LÜSCHER

Studies on the Receptor Sites of the Monoclonal Anti-Pr and -Sa Cold Agglutinins

W. DAHR, D. LICHTHARDT and D. ROELCKE

Relations Between Serum $\alpha_{1}$-Foetoprotein (AFP) and uterine Cytosol Receptors in the Immature Rat: Importance of Fatty Acids Ligands

C. BENASSAYAG, G. VALLETTE, L. SAVU, F. CLERC-HOFMANN,

N. CHRISTEFF, F. MULLER, J. DELORME and E. A. NUNEZ

Specific Binding of the Apo and Holoforms of the Serum DBP to the 'soluble' part of Actin from Human Lymphocytes and Platelets

J. CONSTANS, M. VIAU and C. GOUAILLARD

ACTH Effects on Steroidogenesis and Adrenal Protein Synthesis: Relation Structure-Function

A. DAZORD and J. M. SAEZ

Similarities of the Gaunine Nucleotide Binding Sites Responsible for Adenylate Cyclase Activation and Carbamylcholine Binding Inhibition, In Rat Heart

Membranes

MAGALI WAELBROECK, PIERRE CHATELAIN, PATRICK ROBBERECHT and JEAN CHRISTOPHE 
I. KOUVONEN and R. GRÄSBECK

Receptor-Mediated Endocytosis of Glycosylated Derivatives of Bovine Serum Albumin: Targeting Based on Sugar Recognition

J. QUINTART, J. LIMET and P. BAUDHUIN

Structure-Activity-Relationships in the Steroidal 17ß - Carboxamide Series

P. FORMSTECHER, P. LUSTENBERGER and M. DAUTREVAUX

Binding of Cathepsin B by Haptoglobin

D. BURNETT, N. KALSHEKER and A. R. BRADWELL

\section{B.2. Immunoglobulin Receptors}

Regulation of the Immune Response by the Fc Portion of Immunoglobulin EDWARD L. MORGAN, MARILYN L. THOMAN and WILLIAM O. WEIGLE

Human T-Lymphocytes' Fc-Receptors with High Affinity for Monomeric IgG

M. R. HADAM, J. G. SAAL and H. E. FEUCHT

Isolation of Fcy Receptors Released by Human Lymphocytes

C. SAMARUT, LÊTHIBICHTHUY and J. P. REVILLARD

Cyanogen Bromide Fragments of Mouse IgG2a and IgG2b which Bind to their Fc Receptors on Mouse Macrophages

B. DIAMOND, R. CAMPBELL, J. SCHNECK and B. K. BIRSHTEIN

Anti-Receptor Antibodies: A Comparison in the Rat of the Plasma to Bile

Transfer of Purified IgG, F(ab') 2 and Fab' Antibodies Against Rat Secretory Component (SC)

I. LEMAITRE-COELHO, R. MEYKENS and J. P. VAERMAN

Receptor-Mediated Endocytosis of Polymeric IgA by Cultured Rat Hepatocytes 423 J. N. LIMET, Y.-J. SCHNEIDER, J. P. VAERMAN and A. TROUET

A Neo-Antigen Present on Complex $\alpha_{2} \mathrm{M}$, Related to the Receptor Recognition Site

P. MARYNEN, F. VAN LEUVEN and J. J. CASSIMAN

Events Initiated by Soluble Immune Complex Interaction with Immunoglobulin Receptors on Macrophages

R. G. Q. LESLIE 


\section{B.3. Complement Receptors}

Molecular Weight Analysis of Human Complement (C3) Receptors Isolated by Immunoprecipitation

J. GERDES and H. STEIN

The Receptor Functions of Endogeneous C1q, A Subcomponent of the First Component of Complement, on Peritoneal Macrophages

M. LOOS and H. U. SCHORLEMMER

Receptors for C3b, C3bi, C3d and $\mathrm{B} 1 \mathrm{H}$ on Lymphocytes and Phagocytic Cells M. P. DIERICH, K. P. HAMMANN, H.-H. MUSSEL, M. SCHMITT and O. SCHEINER

\section{B.4. Transferrin and Heme Receptors}

Evidence for Endocytosis of Iron Loaded Transferrin by Cultured Rat Embryo Fibroblasts

J. N. OCTAVE, Y.-J. SCHNEIDER, R. R. CRICHTON and A. TROUET

Transferrin Receptors in Transformation and Differentiation

CHANG-JING G. YEH and W. PAGE FAULK

Mediation of a Receptor Mechanism in the Uptake of Iron from Transferrin by the Hepatocyte

R. M. NUNES, J. M. PRIETO and B. J. POTTER

Iron Uptake by Chinese Hamster Fibroblasts from Human Transferrin

S. SMIT, M. I. E. HUIJSKES-HEINS and B. LEIJNSE

Receptor-Mediated Endocytosis of Heme-Hemopexin by Rat Hepatocytes Y.-J. SCHNEIDER, J. N. LIMET, C. SLACHMUYLDER-OTTE and

A. TROUET

Spectral and Other Studies on the Intestinal Heme Receptor of the Pig

R. GRÄSBECK, I. KOUVONEN and R. MAJURI

\section{B.5. Neurochemical Receptors}

Differentiation between Stereospecific Binding Sites on a Dopamine Receptor Complex: Effects of Proteolytic Enzymes

J. E. LEYSEN and P. VAN GOMPEL 
Neurotensin-Receptor Interactions: Binding and Pharmacological Studies;

Biological Relevance; Structure-Activity Relationships

P. KITABGI

A Novel Triazolopyridazine, ${ }^{3} \mathrm{H}-\mathrm{CL} 218,872$ which Labels the Benzodiazepine Receptor in Rat Brain

H. I. YAMAMURA, T. MIMAKI, M. MORELLI, S. H. YAMAMURA, W. D. HORST, G. BAUTZ and R. O'BRIEN

Immunological Studies of $\beta$ Adrenergic Catecholamine Receptors: A Two-Way Approach

P. O. COURAUD, A. B. SCHREIBER, C. DELAVIER-KLUTCHKO,

C. ANDRÉ, O. DURIEU-TRAUTMANN, B. VRAY, A. SCHMUTZ and A. D. STROSBERG

Asymmetry of Acetylcholinesterase and Acetylcholine Receptor in Intact

Secretory Vesicles from Adrenal Medulla

M. GRATZL and H. KRIEGER-BRAUER

Loss of $\beta_{2}$-Adrenoceptors After Haemophilus Influenzae Vaccination

G. K. TERPSTRA, J. A. M. RAAIJMAKERS and J. KREUKNIET

Characterization of Adrenergic Binding in Canine Lung Tissue

J. A. M. RAAIJMAKERS and G. K. TERPSTRA

\section{B.6. Vasoactive Intestinal Polypeptides (VIP)}

Heterogeneity of VIP-Secretin Receptors in Three Rat Tissues PATRICK ROBBERECHT, PIERRE CHATELAIN, MAGALI WAELBROECK and JEAN CHRISTOPHE

Vasoactive Intestinal Peptide (VIP) Control of Cyclic AMP Accumulation in Digestive Epithelia: Involvement of Multiple Regulatory Processes

M. LABURTHE, B. AMIRANOFF, C. DUPONT, C. GESPACH and G. ROSSELIN

Effects of GTP on Vasopressin, and Angiotensin Binding to Rat Liver Membranes

S. JARD, P. CLAUSER, R. BONO and B. CANTAU

Cholecystokinin in Brain and Hypophysis

J. J. VANDERHAEGHEN, F. LOTSTRA, G. VIERENDEELS,

C. DESCHEPPER, C. GILLES and P. VERBANCK

Vasoactive Intestinal Polypeptide (VIP): Specific Receptors on Smooth Muscle Membranes from Porcine Uterus

B. OTTESEN, P. STAUN-OLSEN, S. GAMMELTOFT and J. FAHRENKRUG 
Impaired Secretin-VIP Sensitivity of Adenylate Cyclase in the Heart of Congenitally Hypertensive (SHR) or Obese ( $\mathrm{fa} / \mathrm{fa}$ ) Rats

PIERRE CHATELAIN, PATRICK ROBBERECHT and JEAN CHRISTOPHE

\section{B. 7. Hormone Receptors}

\section{B.7.1. Insulin Receptors}

Multiple Functions of Peptides: Insulin and Vasoactive Intestinal Polypeptide Bind to Receptors in Liver and Brain

S. GAMMELTOFT, P. STAUN-OLSEN, J. FAHRENKRUG and B. OTTESEN

The Complex Kinetics of Insulin Binding to Receptors on Isolated Pig Hepatocytes

S. GAMMELTOFT, P. STAUN-OLSEN, J. FAHRENKRUG and B. OTTESEN

In Vivo Studies by Gamma-Camera of ${ }^{131}$ I-Insulin Distribution and Metabolism in Rabbits

P. BOURGEOIS, F. LEGROS, M. LANGOHR, A. VERBIST, G. GHANEM and J. FRÜHLING

Immunohistochemical and Autoradiographic Visualization of Porcine and Human ${ }^{125}$ I-Insulin Hepatic Binding In Vivo

P. STEENHOUT, M. GUILLAUME, F. BIERLAIRE, G. GHANEM and

F. LEGROS

\section{B.7.2. Alpha MSH}

Variation of $\alpha$-MSH Receptivity Between Malignant Melanocytes from Horizontal and Vertical Growth Phases in a Human Superficial Spreading Melanoma

F. LEGROS, J. COEL, A. GOSSUIN and F. J. LEJEUNE

${ }^{125} \mathrm{I}-\alpha$-MSH Binding in Human Melanoma Cell Lines

A. GOSSUIN, G. GHANEM, A. TEMMERMAN, J. COEL, P. E. HENRY and F. LEGROS

DNA Replication and Production of Retroviral Markers in Human Melanoma Cultures Depends on Degree of Differentiation and on Hormonal Stimulation N. VAN TIEGHEM, A. VERCAMMEN-GRANDJEAN, M. FOOIJ,

A. TEMMERMAN and F. J. LEJEUNE

Binding of Endogenous $\alpha$-MSH to Malignant Melanocytes in Human Melanomas A. NUCHOWICZ, A. VERHEST, A. GOSSUIN, S. LEGROS, A. LITEANU, P. HANSON, A. SOUPART, F. LEGROS and F. J. LEJEUNE

Hormonal Screening in Patients Suffering Malignant Melanoma. A Preliminary Approach

M. LANGOHR, C. ROBYN, F. LEGROS and F. J. LEJEUNE 


\section{B.7.3. Other Hormones}

Antibodies Against TSH Receptor in Graves' Disease: Evaluation by Release of cAMP

J. M. GÓMEZ, M. A. NAVARRO, M. C. PASTOR and J. SOLER

Antibodies Against TSH Receptor in Graves' Disease: Relation between cGMP/ cAMP Release

M. A. NAVARRO, J. M. GÓMEZ, M. C. PASTOR and J. SOlER

Negative Controls of Dog Thyroid Adenylate Cyclase Cyclic AMP System

P. COCHAUX, J. VAN SANDE and J. E. DUMONT

Rat Liver Glucocorticoid Receptor Purified in Presence of Molybdate

P. LUSTENBERGER, P. FORMSTECHER, M. DAUTREVAUX

Induction of Prolactin Liver Receptors in the Male Rat

P. GOONEWARDENA, P. ENEROTH, A. MODE, G. NORSTEDT and J. Å. GUSTAFSSON

An Affinity Adsorbent for an Estrogen Binding Protein Rat $\alpha$-Fetoprotein

R. ZEEUWS, V. VERSÉE and A. O. BAREL

\section{B.8. Various Receptors}

Receptors for Regulatory Peptides in Epithelial Gut Cancer

M. E. FORGUE-LAFITTE, M. LABURTHE, A. ZWEIBAUM and

G. ROSSELIN

Receptors that Control Acid Secretion in the Isolated Cells from Mammalian

Gastric Mucosa

R. MAGOUS, M. F. LIGNON and J. P. BALI

Microbial Receptors on Human Kidney Epithelia, A Possible Clue in the

Pathogenesis of Bacterial Interstitial Nephritis

J. E. SCHERBERICH, G. JÜNGST, C. GAUHL, W. MONDORF and

W. SCHOEPPE

\section{SECTION C. MONOCLONAL ANTIBODIES}

\section{C.1. Hybridoma Technology}

Human-Mouse Hybridoma Cells Producing Antibodies

GIULIA C. B. ASTALDI, CHARLES WILLEMS, WILMA ALLEYNE, PETER LANDSDORP, WIM P. ZEIJLEMAKER and MARIA JANSSEN 
Production of Rat Monoclonal Antibodies with the LOU Rat Non Secreting IR983F Myeloma Cell Line HERVÉ BAZIN

Anti-Pr, -Gd and Related Cold Agglutinins: Human Monoclonal Antibodies Against Neuraminyl Groups D. ROELCKE, R. BROSSMER and W. EBERT

Analysis of Carbohydrate Determinants on Membranes of Leukemic Leukocytes using Naturally Occurring Monoclonal Human Antibodies (Cold Agglutinins) B. DÖRKEN, D. ROELCKE, B. BOHN and W. HUNSTEIN

A Study of Hybridoma Soft Agar Cloning P. HÉRION, J.-D. FRANSSEN and J. URBAIN

Evaluation of Alternative Screening and Selection Procedures in Hybridoma Technology

H. J. SCHLUSENER and F. W. FALKENBERG

Comparison of Screening Techniques Related to the Production of Monoclonal Antibodies

J. ROZING, P. JOLING, W. VAN EWIJK and C. J. HESSE

A Semi-Automated Enzyme-Linked Immunosorbent Assay (ELISA) to Screen for Hybridoma Cultures Producing Antibody to Carcinoembryonic Antigen (CEA) C. S. WOODHOUSE, C. H. J. FORD and C. E. NEWMAN

Selection of Myeloma Lines Suitable for Hybridoma 645 J.-D. FRANSSEN, P. HÉRION and J. URBAIN

Individual Physical Properties of Mouse Monoclonal Antibodies 649

J. STEENSGAARD

\section{C.2. Definition of Lymphocytes Subsets}

Re-Definition of Human T Cells by Monoclonal Antibodies

P. C. L. BEVERLEY and R. E. CALLARD

Biochemical Studies of Human T Cell Markers COX TERHORST, ANDRÉ VAN AGTHOVEN, JANNIE BORST, KENNETH LE CLAIR and PETER SNOW

Mouse Monoclonal Antibodies Defining Functional Human Lymphocyte Subsets 663

E. P. RIEBER, J. LOHMEYER, D. J. SCHENDEL and G. RIETHMÜLLER

T-Cell Profile and Reactivity In Vitro During Immune Reconstitution Following Bone Marrow Transplantation

J. M. VOSSEN, A. ASTALDI, H. G. DE BRUIN and L. J. DOOREN 
Interaction of Monoclonal Antibodies and Antigen-Specific T-Cell Factor in

Regulation of an Immune Response

M. J. TAUSSIG

Microfluorometric Analysis of Five Monoclonal Antibodies Directed Against Mouse Thymocytes

W. VAN EWIJK, P. W. VAN VLIET, P. L. VAN SOEST, J. ROZING and G. J. VAN DEN ENGH

Binding Characteristics of a Monoclonal Antibody Against Rabbit Thymocytes

J. G. GUILLET, P. MARCHE, J. HOEBEKE and A. D. STROSBERG

Abnormal Helper/Suppressor T-Cell Distribution in Chronic Brucellosis in Humans

D. J. REEN, A. M. EARLY, B. L. HOGAN and R. D. THORNES

Monoclonal Antibodies Defining Rabbit Lymphocyte Subpopulations

W. DE SMET, L. BRYS, M. VAECK and R. HAMERS

The Use of Monoclonal Antibodies to Monitor T-Cell Sub-Populations After Human Cardiac Transplantation M. H. YACOUB, D. J. R. FROUD, M. H. ASHRAF, G. CAMPALANI, A. T. FORSYTH and A. POMERANCE

Monoclonal Anti-B Cell Antibodies: Their Effect on Human Mixed Lymphocyte Reactions

C. M. STEEL, V. VAN HEYNINGEN, K. GUY, B. B. COHEN,

D. L. DEANE, D. CRICHTON and D. HUTCHINS

Monoclonal Antibodies Against Human Thymocytes and T Lymphocytes

W. J. M. TAX, H. W. WILLEMS, M. D. A. KIBBELAAR, J. DE GROOT,

P. J. A. CAPEL, R. M. W. DE WAAL, P. REEKERS and R. A. P. KOENE

Monoclonal Antibodies Against Rat Thymocytes

J. ROZING, P. JOLING, C. J. HESSE and L. M. B. VAESSEN

\section{3. Determination of Histocompatibility Antigens}

Monoclonal Antibodies Against Human MHC Products

P. RICHIARDI, F. MALAVASI, T. CREPALDI, A. O. CARBONARA and

R. CEPPELLINI

Biochemical Analysis of Human HLA-DR Molecules

N. GROSS, R. S. ACCOLLA, G. CORTE and S. CARREL

Functional Analysis of Human Ia Subsets

R. S. ACCOLlA, A. MORETTA and J.-C. CEROTTINI 
Reactivity of Monoclonal Anti-HLA Antibodies with Blood Platelets

P. M. LANSDORP, F. OOSTERHOF, G. C. B. ASTALDI,

W. P. ZEIJLEMAKER

Subsets of Human D Locus Products Identified by a Series of Monoclonal Antibodies

K. GUY, VERONICA VAN HEYNINGEN, B. B. COHEN, D. L. DEANE,

D. CRICHTON and C. M. STEEL

\section{C.4. Viral and Bacterial Detection}

Monoclonal Antibodies Detecting Epstein-Barr Virus Strain and Group Specific Antigenic Determinants

H. HERBST, B. GEORG-FRIES, N. MÜLLER-LANTZSCH,

H. ZUR HAUSEN and D. G. BRAUN

Monoclonal Antibody Against EBV-Associated Transformation Antigen Detected In Vitro and In Vivo

D. A. THORLEY-LAWSON, K. GEILINGER and R. SCHOOLEY

Production of Monoclonal Antibodies Against Poliomyelitis and Rabies Viruses A. D. M. E. OSTERHAUS, A. L. VAN WEZEL, P. VAN DER MAREL and G. VAN STEENIS

A Set of Monoclonal Antibodies to Streptococcal Group Polysaccharide Antigens H. HERBST, D. LAVANCHY and D. G. BRAUN

Hybridoma Antibody Mediated Activation of $\beta-$ Galactosidases from Genetically Defective $E$. Coli

JANE HEWITT, R. JULIAN, S. DUNCAN and PETER D. WESTON

Characterization of Monoclonal Antibodies to Subunit A of Cholera Toxin

A. KUROSKY, L. K. DUFFY and R. M. DENNEY

Production of Monoclonal Antibodies Against Mycoplasma Hyorhinis as a

Secondary Effect of Immunisation of Mice with Cultured Cell Lines

C. VENNEGOOR, A. A. POLAK-VOGELZANG and A. HEKMAN

\section{C.5. Detection of Proteins}

Monoclonal Antibodies to the Human Leukocyte Interferons and Their Use for Interferon Purification and a Quantitative Interferon Assay

T. STAEHELIN, B. TAKÁCS, B. DURRER, J. SCHMIDT, J. STOCKER, V. MIGGIANO, C. STÄHLI, D. S. HOBBS, H.-F. KUNG and S. PESTKA

Radioimmunoassay (RIA) of Post-Gamma Globulin Using a Monoclonal Antibody

T. SEKINE, D. J. PERRY, S. RAGHEEB and M. D. POULIK 
Localization of Collagen Type IV in Basement Membranes by Monoclonal Antibodies

H. G. FOELLMER, J. A. MADRI, R. T. WYATT and H. FURTHMAYR

Study of $\alpha_{1}$ Microglobulin (HC Protein) with Monoclonal Antibodies

C. VINCENT, J. P. REVILLARD, P. BOUIC and J. BROCHIER

Anti-Idiotypic Monoclonal Antibodies Against Myasthenic Antibodies

R. W. JAMES, A.-K. LEFVERT, C. ALLIOD and B. W. FULPIUS

Quantitation of IgGkappa and IgGlambda in Normal and Pathological Sera

M. PRIOR, N. R. LING, J. LOWE, S. EVANS, K. MAY and R. JEFFERIS

Use of Monoclonal Antibodies in the Characterisation of Immunoglobulin Classes and Subclasses in Animal Species

K. MAY, S. SENIOR, M. M. GANI, P. PORTER, R. JEFFERIS and N. LING

Monoclonal Antibodies Directed Against a Torpedo Electric Organ Membrane Antigen

A. C. VON GERSTENBERG, U. LøVBORG, C. M. KOCH and E. BOCK

\section{C.6. Identification of Lipids}

Monoclonal Antibodies Against Membrane Glycolipids of an Anti-Streptococcal Group A B-Cell Hybridoma

R. K. BALL, H. HERBST, C. A. SCHÖNENBERGER, G. ROSENFELDER and D. G. BRAUN

Monoclonal Antibody Secreting Mouse Hybridoma Clones Express Different

Sets of Membrane Glycosphingolipids in Different Antigenic Systems

G. ROSENFELDER, H. HERBST, S. S. ALKAN, CH. HEUSSER and

D. G. BRAUN

Glycosphingolipid Patterns of Established Human Hematopoietic Cell Lines

G. ROSENFELDER, A. ZIEGLER, P. WERNET and D. G. BRAUN

Monoclonal Antibodies to Tumor-Associated Glycolipids: Preparation and Application for Suppression of Tumor Growth

W. W. YOUNG, JR, D. L. URDAL and S. HAKOMORI

Monoclonal Antibodies Against Human Milkfat Globule Membranes Detecting Differentiation Antigens of the Mammary Gland

J. HILKENS, F. BUIJS, J. HILGERS, PH. HAGEMAN, A. SONNENBERG,

U. KOLDOVSKY, K. KARANDE, R. P. VAN HOEVEN, C. FELTKAMP and J. M. VAN DE RIJN 


\section{C.7. Determination of Hormones}

Monoclonal Antibodies in Clinical Diagnosis - Reagents for Detecting Hormones and Immunoglobulins

L. WANG, C. S. HEXTER and M. INBAR

Production of Monoclonal Antibodies to Steroid Hormones

Z. ESHHAR, F. KOHEN and H. R. LINDNER

Monoclonal Antibodies Against Growth Hormone: Effects on the Hormone Interaction with Specific Cell Surface Receptors

L. A. RETEGUI, P. DE MEYTS and P. L. MASSON

Monoclonal Antibodies Against Human Growth Hormone

I. JÓNSDÓTTIR, P. PERLMANN and H. P. T. EKRE

Characteristics of Monoclonal Antibodies Against Human Chorionic Gonadotrophin (HCG)

A. M. G. BOSCH, W. STEVENS, A. SCHUURS, O. SCHÖNHERR and H. ROELOFS

Sensitive and Specific RIA for Human Chorionic Gonadotropin (hCG) Using Monoclonal Antibodies

P. TANNER, U.-H. STENMAN, M. SEPPÄLÄ and J. SCHRÖDER

The Use of Monoclonal Antibodies Against Prolactin (Prl) in a Solid Phase Enzyme-Immunoassay (EIA)

H. VAN DEN BERG, L. DRIEDONKS, H. v. GRINSVEN and A. SCHUURS

Mouse Monoclonal Antibodies Against Human Prolactine

S. KAUL, D. DRAHOVSKY and A. WACKER

Monoclonal Antibodies to Human Prolactin and Chorionic Somatomammotropin

J. IVANYI and PAT DAVIES

Monoclonal Thyroglobulin-Autoantibodies as a Tool to Study Autoimmunity

G. GUARNOTTA, R. QUARTEY-PAPAFIO, J. TEMPLEMAN,

L. C. P. DE CARVALHO and I. M. ROITT

\section{C.8. Determination of Enzymes}

Monoclonal Antibodies Against Two Antigens of Clinical Interest

C. STÄHLI, P. HÄRING, T. STAEHELIN, J. SCHMIDT, R. MUGGLI,

P. HUBER and V. MIGGIANO 
Monoclonal Antibodies Against Human Acid $\alpha$-Glucosidase

J. HILKENS, J. M. TAGER, F. BUIJS, B. BROUWER-KELDER,

G. M. VAN THIENEN, F. P. W. TEGELAERS, R. KALSBEEK and

J. HILGERS

High-Affinity Monoclonal Autoantibody Used as a Reagent in a RIA for Human Creatine Kinase BB

P. URDAL, P. KIERULF and J. H. STROMME

\section{C.9. Detection of Cancer Antigens}

Five Melanoma-Associated Antigens Identified by Monoclonal Antibodies

K. E. HELLSTRÖM, I. HELLSTRÖM, J. P. BROWN, M.-Y. YEH and

R. G. WOODBURY

Antigen Expression and Immune Lysis of Human Melanoma Cells: Analysis with Monoclonal Antibodies

K. IMAI, A. YACHI, A.-K. NG and S. FERRONE

Reactions of Monoclonal Antibodies Against Human Melanoma with Different Tissues and Cell Lines

PH. HAGEMAN, C. VENNEGOOR, M. VAN DER VALK, J. LANDEGENT, A. JONKER and L. VAN DER MISPEL

Molecular Heterogeneity of a High Molecular Weight Human Melanoma

Associated Antigen (MAA) Detected by Monoclonal Antibodies

K. IMAI, B. S. WILSON, G. RUBERTO, T. NAKANISHI, A. YACHI and

S. FERRONE

A Monoclonal Antibody Defining a Burkitt Lymphoma Associated Antigen

J. WIELS, M. FELLOUS, G. LENOIR and T. TURSZ

Preparation and Characterization of Monoclonal Antibodies Against Antigens of Human Renal Adenocarcinoma

H. HESS, U. ALHEID, S. BIERMANN, T. WAKS, J. E. SCHERBERICH,

A. W. MONDORF, W. SCHOEPPE, T. SENGE and F. W. FALKENBERG

Monoclonal Antibodies Against Carcinoembryonic Antigen (CEA)

A. HEDIN and S. HAMMARSTRÖM

Characterisation of Monoclonal Antibodies to Carcinoembryonic Antigen by Antibody Overlay of Polyacrylamide Slab Gels

K. A. CHESTER and R. H. J. BEGENT

\section{C.10. Drug Targeting}

Phase I Trials of Murine Monoclonal Antibodies to Tumor Associated Antigens: Preliminary Observations

R. O. DILLMAN, R. E. SOBOL and I. ROYSTON 
xxiv

The Potential Use of Monoclonal Antibodies in Drug Targeting

G. F. ROWLAND, R. G. SIMMONDS, J. R. F. CORVALAN,

C. H. MARSDEN, J. R. JOHNSON, C. S. WOODHOUSE, C. H. J. FORD and C. E. NEWMAN

Specific Killing of Human and Mouse Tumor Cells by Immunotoxins

P. CASELLAS, H. E. BLYTHMAN, J. P. BROWN, O. GROS, P. GROS,

K. E. HELLSTRÖM, I. HELLSTRÖM, F. K. JANSEN, P. PONCELET and

H. VIDAL

Drug Targeting with Monoclonal Antibodies

M. PAGE, J. P. EMOND, C. GAUTHIER, C. DUFOUR and L. INNES

Analysis of Human Haemopoietic Precursor Cell Antigens Using Astatine

Labelled Monoclonal Antibodies

G. BROWN, W. BATEMAN, J. COWAN, A. G. FISHER, D. TOKSOZ and A. T. M. VAUGHAN

\section{SECTION D. NEW METHODS}

The IGS (Immuno Gold Staining) Method Used with Monoclonal Antibodies

J. DE MEY, M. MOEREMANS, M. DE WAELE, G. GEUENS and

M. DE BRABANDER

Enumeration of $\mathrm{T}$ Lymphocytes and their Subclasses in Peripheral Blood by Immunogold Staining

M. DE WAELE, J. DE MEY, M. MOEREMANS and B. VAN CAMP

Chromatofocusing: A New High Resolution Method for Protein Fractionation L. SÖDERBERG, T. LÅ ̊ and D. LOW

The Multiwire Proportional Counter for the Study of Ligand-Binding of Serum

Proteins

B. J. SCOTT, J. E. BATEMAN, M. R. HAWKESWORTH, D. BURNETT and A. R. BRADWELL

Identification of Specific Antigens or Antibodies After Electrophoretic Transfer. Application to Measles Virus

D. KARCHER, A. LOWENTHAL, H. THORMAR and M. NOPPE

SUBJECT INDEX 


\title{
ASYMMETRY OF ACETYLCHOL- INESTERASE AND ACETYLCHOLINE RECEPTOR IN INTACT SECRETORY VESICLES FROM ADRENAL MEDULLA
}

\author{
M. GRATZL and H. KRIEGER-BRAUER \\ Department of Physiology and Chemistry, University of Saarland, \\ D-665 Homburg/Saar, F.R.G.
}

\begin{abstract}
Highly purified secretory vesicles from adrenal medulla, isolated by differential and density gradient centrifugation using isotonic gradient material (PercollTM), contain acetylcholinesterase. The enzyme was latent in isolated secretory vesicles i.e. acetylcholinesterase was inaccessible to added substrate. The enzyme activity became patent after addition of detergent or in hypotonic media. Hypotonic treatment or specific lysis of the vesicles with $\mathrm{Mg}^{2+} / \mathrm{ATP}$ in the presence of a permeant anion resulted in the release of soluble acetylcholinesterase from the vesicular content. Membrane-bound enzyme sedimented with the membranes. Binding of a-bungarotoxin could only be observed when secretory vesicles were lyzed.

It is concluded, that the acetylcholine receptor as well as the membrane-bound form a acetylcholinesterase are localized on the inner surface of the secretory vesicle membrane, which becomes the outer surface of the cell membrane during exocytosis. Concomitantly the soluble form of acetylcholinesterase present within secretory vesicles is released into the extracellular fluid.
\end{abstract}

\section{KEYWORDS}

Acetylcholinesterase; acetylcholine receptor; secretory vesicles; adreral medulla.

\section{INTRODUCTION}

During exocytosis secretory vesicle contents are released into the extracellular fluid and their limiting membranes are incorporated into the cell membrane. In this way the inside of the secretory vesicle membrane becomes the outside of the cell membrane. The existence of cell membrane components on the inner surface of secretory vesicle membranes would be consistent with a biogenetic relationship between the secretory vesicle and the cell membrane. In this report we describe evidence for the location of such cell membrane components, the acetylcholinesterase and the acetylcholine receptor of the chromaffin cell, within secretory vesicles.

RESULTS AND DISCUSSION

Secretory vesicles from adrenal medulla, isolated by differential cen- 
trifugation, were further purified on a continuous self generating Percoll TM gradient. An osmolality of 420 mosmol/kg was maintained throughout the procedure. In this way highly purified secretory vesicles wereiobtained that leaked intravesicular adrenalin only slowly (Gratzl,Krieger-Brauer and Ekerdt, 1981).

The vesicles were found to contain acetylcholinesterase with a specific activity of about 14 nmoles substrate hydrolyzed per min'and mg protein (=total activity, determined in the presence of $0.2 \%$ Triton $X$ 100). With no detergent added and in media of an osmolality of 420 mosmol/kg enzyme activity amounted only to about $4 \%$ of the total activity (Fig. 1).

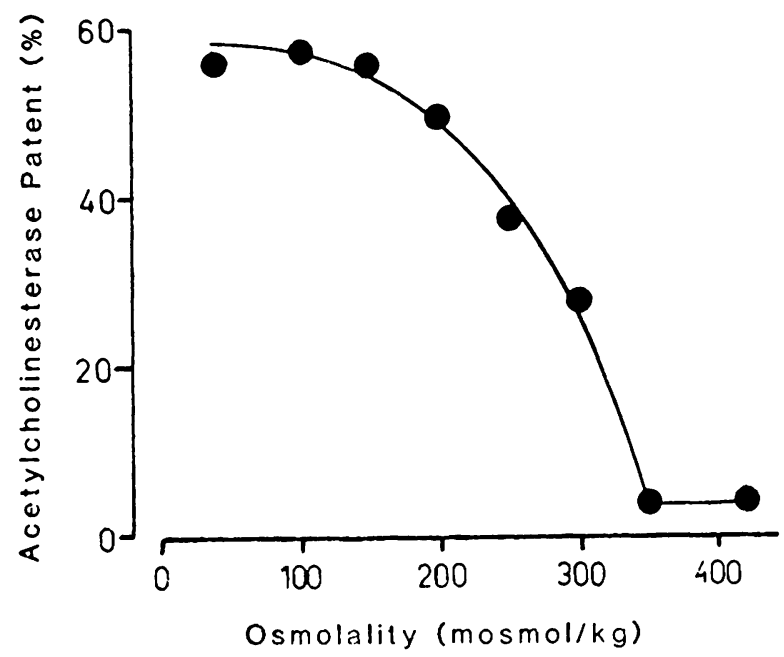

Fig.1. Latency of acetylcholinesterase of isolated secretory vesicles. The vesicles were incubated for $5 \mathrm{~min}$ at room temperature in sucrose media of different osmolalities. The enzyme activity was determined without detergent added or with $0.2 \%$ Triton $\mathrm{X} 100$ present $(100 \%)$.

Reduction of the osmolality results in an increase of the enzyme activity. Below $200 \mathrm{mosmol} / \mathrm{kg}$, an osmolality at which the vesicles have depleted all their intravesicular adrenalin (Gratzl,1980), no further increase in enzyme activity could be detected (Fig.1). During hypotonic treatment (200 mosmol/ $\mathrm{kg}$ ) of secretory vesicles about one third of the total acetylcholinesterase was released into the supernatant (Table 1), while the remaining activity sedimented with the membranes. obviously a membrane-bound pool of acetylcholinesterase exists within secretory vesicles along with the soluble pool which could also be released from the vesicles by $2 \mathrm{mM} \mathrm{Mg} 2+/ \mathrm{ATP}$ in the presence of $\mathrm{KCl}$, but not in the presence of sucrose (Table 1). Lysis of secretory vesicles as a consequence of an ATP driven proton pump in the presence of a permeant anion has been described earlier (Casey and Colleagues, 1976). Recently we have detected, that the membrane-bound form of acetylcholinesterase can be distinguished from the soluble enzyme by its electrophoretic mobility (Gratzl, Krieger-Brauer and Ekerdt, 1981). 
Table 1 RELEASE OF ACETYLCHOLINESTERASE FROM ISOLATED SECRETORY VESICLES

\begin{tabular}{|c|c|c|}
\hline Medium & $\begin{array}{l}\text { Osmolality } \\
\text { (mosmol/kg) }\end{array}$ & $\begin{array}{l}\text { Acetylcholinesterase } \\
\text { in Supernatant ( } \%)\end{array}$ \\
\hline $\begin{array}{l}\text { Sucrose } \\
\text { KCl } \\
\text { Sucrose, } \mathrm{Mg}^{2+} / \text { ATP }\end{array}$ & $\begin{array}{l}420 \\
420 \\
420\end{array}$ & $\begin{array}{l}3.3 \\
4.7 \\
2.6\end{array}$ \\
\hline $\begin{array}{l}\mathrm{KCl}, \mathrm{Mg}^{2+} / \mathrm{ATP} \\
\text { Sucrose }\end{array}$ & $\begin{array}{l}420 \\
200\end{array}$ & $\begin{array}{l}23.6 \\
32.6\end{array}$ \\
\hline
\end{tabular}

Isolated secretory vesicles were incubated for 30 min at $37^{\circ} \mathrm{C}$ in $20 \mathrm{~mm}$ Mops, $\mathrm{pH} 7.0,1 \mathrm{mM}$ EGTA and sucrose or $\mathrm{KCl}$ to obtain the final osmolality as indicated. The concentration of $\mathrm{Mg}^{2+}$ and ATP was $2 \mathrm{mM}$. The mixtures were centrifuged for $10 \mathrm{~min}$ at $130000 \mathrm{~g}_{\mathrm{av}}$ in a Beckman AirfugeTM and the enzyme activity was determined in the supernatant. Total enzyme activity $(=100 \%)$ was determined in the presence of $0.2 \%$ Triton $X 100$.

The experiments described so far show, that secretory vesicles from adrenal medulla contain two types of acetylcholinesterase, both sequestered by the vesicular membrane from the surrounding medium. One type is membrane-bound, but faces the intravesicular space, the other type is part of the vesicular content. In the following we provide evidence, that also the acetylcholine receptor is arranged in an asymmetric way in the secretory vesicle membrane, namely on the inner surface. a-bungarotoxin did not bind to intact secretory vesicles. However, when the vesicles were lyzed in the presence of the venom, specific binding was observed (Fig.2).

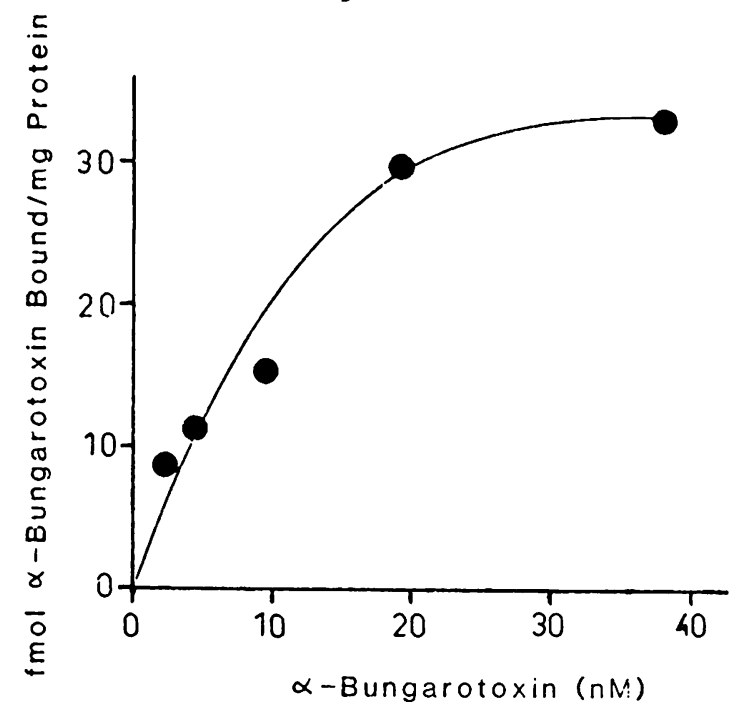

Fig. 2 Binding of $\left[{ }^{3} \mathrm{H}\right]$ a-bungarotoxin to secretory vesicles. 
Isolated secretory vesicles were lyzed hypotonically (final osmolality 170 mosmol. $/ \mathrm{kg}$ ) in the presence of different concentrations of [3 ${ }^{3}$ ] a-bungarotoxin or $\left[{ }^{3} \mathrm{H}\right]$ a-bungarotoxin plus a constant amount of unlabelled a-bungarotoxin $\left(5 \times 10^{-7} \mathrm{M}\right)$. Incubation was continued for $45 \mathrm{~min}$ at room temperature. Membranes were separated from the medium in a sucrose step gradient. The radioactivity of the material recovered from the gradient was determined by liquid scintillation counting. Specific binding was obtained from the difference between the amount of $\left[{ }^{3} \mathrm{H}\right]$ a-bungarotoxin bound in the absence and the presence of unlabelled a-bungarotoxin.

At the concentration of $40 \mathrm{nM}$ specific binding of a-bungarotoxin was approximately saturated and the number of binding sites was 33 fmole/ $\mathrm{mg}$ membrane protein. Saturation of a-bungarotoxin binding sites of cell membranes isolated from adrenal medulla was observed at $4 \mathrm{nM}$ and the number of sites was $190 \mathrm{fmole} / \mathrm{mg}$ membrane protein (Wilson and Kirshner, 1977).

Concerning the distribution and the transport of acetylcholinesterase and acetylcholine receptor, interesting parallel observations have been made with chromaffin cells as well as with myoblasts. Both types of cells in culture release soluble acetylcholinesterase into the medium (Rotundo and Famborough, 1980a, Rotundo and Famborough, 1980, Mizobe and Livett, 1980). In myoblasts, newly formed acetylcholinesterase and acetylcholine receptors were found localized within intracel.lular organelles. Although acetylcholinesterase is secreted in a $\mathrm{Ca}^{2}+$-dependent manner by stimulated adrenal glands, the mechanism of this process remained obscure (Chubb and Smith,1975a, Chubb and Smith, 1975b, Somogyi and Colleagus, 1975). Since it has been shown now, that acetylcholinesterase (as well as acetylcholine receptor) is present within adrenal medullary secretory vesicles, an exocytotic pathway is likely to occur.

\section{ACKNOWLEDGMENT}

We thank Mrs.M.Elis for excellent technical assistance and for typing the manuscript. This work was supported by the Sonderforschungsbereich 38 "Membranforschung" of the Deutsche Forschungsgemeinschaft.

\section{REFERENCES}

Casey,R.P.,D.Njus, G.K.Radda, and P.A.Sehr (1976).Biochem.J.158,583-588. Chubb,I.W., and A.D.Smith (1975a). Proc.R.Soc.Lond.B, 191,245-261. Chubb,I.W., and A.D.Smith (1975b). Proc.R.Soc.Lond.B, 191,263-269. Gratzl,M. (1980). Transport of membranes and vesicle contents during exocytosis. In T.Bücher, W.Sebald, H.Weiss (Eds), Biological Chemistry of Organelle Formation, springer Verlag, Berlin, Heidelberg, pp 165-174.

Gratzl,M. H.Krieger-Brauer, and R.Ekerdt (1981). Biochim.Biophys.Acta submitted

Mizobe,F., and B.G.Livett (1980). J.Neurochemistry 35, 1469-1473.

Rotundo,R.L., and D.M.Famborough (1980). Cell, 22,583-594.

Rotundo,R.L., and D.M.Famborough (1980). Cel1, 22,595-602.

Somogyi,P., I.W.Chubb, and A.D.Smith (1975). Proc.R.Soc.Lond.B, 191, $271-283$.

Wilson, S.P., and N.Kirshner (1977). J.Neurochemistry 28,687-695. 


\section{AUTHOR INDEX}

Accolla R.S. 713, 719

Acevedo F. 263

Airoldi G. 337

Akahonai Y. 93

Albeck M.J. 151

Alexandrov I. 159

Alheid U. 903

Alkan S.S. 801

Allegrini P.R. 27

Alleyne W. 609

Alliod C. 781

Alonzo A. 231

Amiranoff B. 513

André C. 493

Ashraf M.H. 691

Astaldi A. 667

Astaldi G.C.B. 609, 723

Aubery M. 341,345

Baffet G. 183

Bailyes E.M. 33

Balduini C. 337

Bali J.P. 599

Ball R.K. 797

Ballmer K. 307

Barel A.O. 591

Barlati S. 299, 303

Bateman J.E. 961

Bateman W. 937

Baudhuin P. 389

Bause E. 57

Bautz G. 487

Bazin H. 615

Begent R.H.J. 911

Benassayag C. 369

Berek C. 247
Bernard B. 341,345

Beverley P.C.L. 653

Beyreuther K. 57

Bierlaire F. 547

Bierman S. 903

Biermé R. 79

Bijlenga R.K.L. 45

Birchmeier W. 287

Birshtein B.K. 415

Björck L. 191

Blommesteyn A.C. 271

Blythman H.E. 927

Bock E. 151, 155, 793

Boer P. 67

Bohn B. 623

Böhni P. 259

Boneu B. 79

Bonnafous J.C. 147

Bono R. 517

Borst J. 659

Bosch A.M.G. 837

Bosman-Jacobs E.P. 271

Bosman G.J.C.M. 67

Bouic P. 777

Bourgeois P. 543

Bradwell A.R. 397, 961

Braun D.G. 735, 747, 797 , 801,805

Brochier J. 777

Brodbeck U. 105, 109

Bron C. 133, 255

Brossmer R. 619

Brouwer-Kelder B. 869

Brovelli A. 337

Brown G. 937

Brown J.P. 877, 927

Bruynzeel P.L.B. 163, 167 
Brys L. 687

Buijs F. 813, 869

Burger M.M. 307

Burnett D. 397,961

Bygdeman M. 195

Byström B. 195

Callard R.E. 653

Campalani G. 691

Campbell R. 415

Cantau B. 517

Cantrell J.L. 213

Capel P.J.A. 701

Capron A. 179

Carbonara A.0. 709

Carrel S. 713

Casellas P. 927

Cassiman J.J. 427

Ceppelini R. 709

Cerottini J.C. 133, 719

Changeux J.P. 351

Chap H.J. 79

Chatelain P. 381, 509, 531

Chester K.A. 911

Christeff N. 369

Christiansson A. 175

Christophe J. 381, 509, 531

Cigén R. 191

Clas F. 317

Clauser P. 517

Clemetson K.J. 359

Clerc-Hoffmann F. 369

Cleve $\mathrm{H} .3$

Cochaux P. 579

Coel J. 551, 555

Cohen B.B. 695, 729

Coligan J.E. 187, 237

Colombi M. 299

Comoglio P.M. 291

Constans J. 373

Conway T.P. 201

Corradin G. 133

Corte G. 713

Corvalan J.R.F. 921

Couraud P.O. 493

Cowan J. 937

Crepaldi T. 709

Crichton D. 695, 729

Crichton R.R. 447

Dahr W. 57, 365

Daum G. 259

Dautrevaux M. 393, 583

Davies P. 855
Dazord A. 377

Deane D.L. 695, 729

De Brabander M. 943

de Bruin H.G. 667

de Carvalho L.C.P. 861

de Groot J. 701

De Mey J. 943, 949

De Meyts P. 827

De Mulder A. 329

de Petro G. 303

de Rooij F.W.M. 271

De Smet W. 687

de Vaux Saint Cyr C. 159

de Waal R.M.W. 701

De Waele M. 943, 949

Debuire B. 41

Delavier-Klutchko C. 493

Delorme J. 369

Denney R.M. 755

Desai P.R. 213

Deschepper C. 521

Diamond B. 415

Dierich M.P. 443

Dillman R.O. 915

Dissous C. 179

Dooren L.J. 667

Dornand J . 147

Dörken B. 623

Dorset D.L. 171

Douste-Blazy L. 79

Drahovsky D. 851

Driedonks L. 847

Duffy L.K. 755

Dufour C. 933

Dumont I. 333

Dumont J.E. 579

Duncan R.J.S. 751

Dupont C. 513

Durieu-Trautman O. 493

Durrer B. 763

Duthu A. 159

Early A.M. 683

Ebert W. 619

Ekre H.P.T. 833

Emond J.P. 933

Eneroth P. 195, 587

Engel A. 171

Engers H. 133

Esshar Z. 823

Evans S. 785,789

Fahrenkrug J. 527, 535, 539

Falkenberg F.W. 631, 903 
Faulk W.P. 89,451

Fellous M. 899

Feltkamp C. 813

Ferrone S. 883, 893

Festenstein H. 205, 231

Feucht H.E. 405

Fischer A.G. 937

Foellmer H.G. 773

Font J. 341

Fooij M. 559

Ford C.H.J. 641, 921

Forgue-Lafitte M.E. 595

Formstecher P. 393, 583

Forsyth A.T. 691

Franssen J.-D. 627, 645

Frobert Y. 295

Fröman G. 263

Froud D.J.R. 691

Frühling J. 543

Fulpius B.W. 781

Furthmayr H. 49, 773

Galetto G. 291

Gamme l toft S. 527, 535, 539

Garavito R.M. 171

Gasser S. 259

Gates F.T. III 187

Gauhl C. 139, 603

Gauthier C. 933

Geering K. 255

Geilinger K. 739

Georg-Fries B. 735

Gerdes J. 435

Geser D. 255

Gespach C. 513

Geuens G. 943

Gibson J. 259

Gilles C. 521

Gillois M. 79

Giphart M.J. 243

Girardet M. 255

Ghanem G. 543, 547, 555

Glasebrook A. 133

Gomez J.M. 571,575

Goonewardena P. 587

Gossuin A. 551, 555, 563

Gouaillard C. 373

Gräsbeck R. 385, 467

Gratzl M. 497

Greaves M.F. 227

Gros O. 927

Gros P. 927

Gross N. 713

Guarnotta G. 861

Guguen-Guillouzo C. 341

Guillaume M. 547

Guillet J.G. 679
Guillouzo A. 341

Gustafsson J.A. 587

Guy K. 695, 729

Hadam M.R. 405

Haddada H. 159

Hageman P. 813, 889

Hakomori S. 809

Haldeman A. 27

Hamelink M.L. 167

Hamers R. 687

Hamman K.P. 443

Hammarström S. 907

Hanley M. 477

Hanson P. 563

Häring P. 865

Hawkesworth M.R. 961

Hedin A. 907

Heidmann T. 351

Hekman A. 759

Helenius A. 101

Herbst F. 113, 121

Herbst H. 735, 747, 797, 801

Hellström I. 877,927

Hellström K.E. 877,927

Henry P.E. 555

Hérion P. 627, 645

Hess H. 903

Hesse C.J. 637, 705

Heusser C. 801

Hewitt J. 751

Hexter C.S. 817

Hilgers J. 813, 869

Hilkens J. 813, 869

Hjertén S. 15

Hobbs D.S. 763

Hoebeke J. 679

Hoessli D.C. 63, 71

Hogan B.L. 683

Höglund S. 101

Hooghe R. 71

Hooghe R.J. 247

Hooghe-Peters E.L. 247

Horst W.D. 487

Horvath C. 133

Huang R.T.C. 321

Huber P. 865

Huijskes-Heins M.I.E. 459

Hunstein W. 623

Hutchins D. 695

Imai K. 93, 883, 893

Inbar M. 817

Innes L. 933

Ivanyi J. 855

Iversen L. 477 
Jägersten C. 175, 251

James R.W. 781

Jansen F.K. 927

Janssen M. 609

Jard S. 517

Jaton J.C. 45

Jefferis R. 785, 789

Johansson K.-E. 175, 251

Johnson K.R. 921

Joling P. 637, 705

Jonker A. 889

Jonsdottir I. 833

Jungst G. 603

Kalsbeek R. 869

Kalsheker N. 397

Kampmann L. 275

Karande K. 813

Karcher D. 965

Kauffman H.F. 163

Kaul S. 851

Kawaharada M. 93

Kay M.M.B. 325

Kennes B. 329, 333

Kibbelaar M.D.A. 701

Kierulf P. 873

Kimball E.S. 187,237

Kindt T.J. 187, 237

Kinne R. 139

Kinnon C. 221

Kissonerghis A.-M. 221

Kitabgi P. 483

Koch C.M. 793

Kocher H.P. 45

Koene R.A.P. 701

Kohen F. 823

Koldovsky U. 813

Kordowicz M. 57

Kouvonen I. 385, 467

Kreukniet J . 501

Krieger-Brauer H. 497

Kung H.-F. 763

Kunicki T. 85

Kurosky A. 755

Laas T. 955

Laburthe M. 513, 595

Landegent J . 889

Langohr M. 543, 567

Lansdorp P. 609, 723

Larizza L. 299

Lavanchy D. 747

Lawson W.J. 125

Leben L. 231

LeClair K. 659

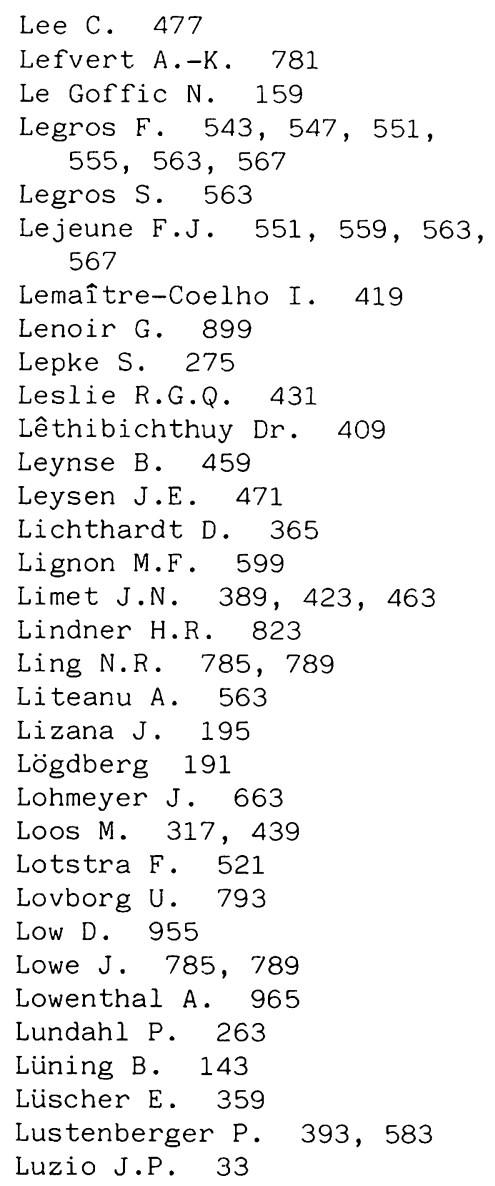


Mimaki T. 487

Mode A. 587

Moeremans M. 943, 949

Moest P. 329

Mondorf A.W. 903

Mondorf $W .139,603$

Norein B. 101

Morelli M. 487

Moretta A. 719

Morgan E.L. 401

Mottura A. 299

Muggli R. 865

Muller F. 369

Muller-Lantzsch N. 735

Mussel H. $-\mathrm{H} .443$

Naim H.Y. 359

Nairn R. 237

Nakanishi T. 893

Nathenson S.G. 237

Navarro M.A. 571,575

Nève P. 329,333

Newby A.C. 33

Newman C.E. 641, 921

Newman R.A. 227

$\mathrm{Ng} \mathrm{A.}-\mathrm{K} . \quad 883$

Noppe M. 965

Norstedt G. 587

Nuchowicz A. 563

Nunes R.M. 455

Nunez E.A. 369

Nurden A.T. 85

O'Brien R. 487

Octave J.N. 447

Ohashi A. 259

Oosterhof F. 723

Osterhaus A.D.M.E. 743

O'Sullivan M.J. 89

Oswald R.E. 351

ott P. 105, 109

Ottesen B. 527, 535, 539

Owen M.J. 221

Page M. 933

Pallavicini G. 337

Pan H. 15

Pappert G. 117

Passow H. 275

Pastor M.C. 571, 575

Perlmann P. 833

Perry D.J. 769

Persson H. 97

Pestka S. 763

Philipson L. 97
Phutrakul S. 263

Pidard D. 85

Pink J.R.L. 71

Piro P. 333

Polak-Vogelzang A.A. 759

Pomerance A. 691

Poncelet P. 927

Potter B.J. 455

Poulik M.D. 201, 769

Prieto J.M. 455

Prior M. 785, 789

Putnam F.W. 41

Quartey-Papafio R. 861

Quintart J. 389

Raaijmakers J.A.M. 167, 501,505

Rabbits T.H. 37

Ragheeb S. 769

Rampoldi E. 299

Reekers P. 701

Reen D. 683

Retegui L.A. 827

Revillard J.P. 209, 409, 777

Rice-Evans C. 125

Richiardi P. 709

Rickart F. 329

Rieber E.P. 663

Riethmuller G. 663

Riezman H. 259

Robberecht P. 381, 509, 531

Robyn C. 567

Roelcke D. 365, 619, 623

Roelofs H. 837

Roitt I.M. 861

Roos E. 313

Rosa J.P. 85

Rosenbusch J.P. 171

Rosenfelder G. 797, 801, 805

Rosselin G. 513, 595

Rott R. 321

Rowl and G.F. 921

Royston I. 915

Rozing J. 637, 675, 705

Ruberto G. 893

Rudl off V. 113, 121

Rungger-Brändle E. 63

Saal J.G. 405

Saez J.M. 377

Samarut C. 409

Sandberg B. 477 
Sanderson A.R. 205

Savu L. 369

Schatz G. 259

Scheiner 0. 443

Schendel D.J. 663

Scherberich J.E. 139, 603, 903

Schlüsener H.J. 631

Schmid M. 133

Schmidt J. 763, 865

Schmidt $W . \quad 205,231$

Schmitt M. 443

Schmutz A. 493

Schneck J. 415

Schneider Y. -J. 423, 447, 463

Schoeppe W. 139, 603, 903

Schönenberger C.A. 797

Schönherr 0. 837

Schooley R. 739

Schorlemmer H.U. 439

Schreiber A.B. 493

Schreier M. 71

Schröder J. 843

Schubert D. 117, 121

Schuurs A. 837,847

Scott B.J. 961

Sekine T. 769

Senge T. 903

Seppälä M. 843

Siadak A.W. 247

Siddle K. 33

Sié P. 79

Sigrist $\mathrm{H} .27$

Simmonds R.G. 921

Simons K. 101

Slachmuylder-Otte C. 463

Smit S. 459

Smith R.H. 125

Snow P. 659

Sobol R.E. 915

Söderberg L. 955

Soler J. 571, 575

Sonnenberg A. 813

Soupart A. 563

Springer G.F. 213, 217

Staehelin T. 763, 865

Stähli C. 763, 865

Staun-Olsen P. 527, 535, 539

Steel C.M. 695, 729

Steensgaard J. 649

Steenhout P. 547

Stein H. 435

Stein-Parvé E.P. 67

Stenman U. $-\mathrm{H} .843$

Stevens W. 837

Stocker J. 763
Stromme J.H. 873

St:oskerg A.D. 493, 679

Sundquist B. 101

Sutherland D.R. 227

Tager J.M. 869

Takacs B. 763

Tanner P. 843

Tarone G. 291

Taussig M.J. 671

Tax W.J.M. 701

Tegelaers F.P.W. 869

Tegtmeyer H. 213, 217

Temmerman A. 555, 559

Templeman J. 861

Tenchini M. 299

Terhorst C. 659

Terpstra G.K. 501, 505

Thoman M.L. 401

Thorley-Lawson D.A. 739

Thormar H. 965

Thornes R.D. 683

Toksoz D. 937

Trouet A. 423, 447, 463

Tursz T. 899

Uehara H. 237

Urbain J. 627, 645

Urdal D.L. 809

Urdal P. 873

Vaeck M. 687

Vaerman J.P. 419, 423

Vaessen L.M.B. 705

Vaheri A. 303

Vallette G. 369

van Agthoyen A. 659

Van Camp B. 949

van de Pavert I.V. 313

van de Rijn J.M. 813

van den Berg $\mathrm{H} . \quad 847$

van den Berg J.W.O. 271

van den Bogaard W. 163, 167

van den Engh G.J. 675

van der Feltz M.J.M. 243

van der Hofstadt G.A.J.M. 75

van der Korput J.A.G.M. 243

van der Marel P. 743

van der Mispel L. 889

van der Valk M. 889

van de Rijn J.M. 813

van Ewijk W. 637, 675

Van Gompel P. 471

van Heyningen V. 695, 729 
van Hoeven R.P. 813

Van Leuven F. 427

Van Rymenant M.E. 75

Van Sande J. 579

van Soest P.L. 675

van Steenis G. 743

van Steveninck J. 129

van Thienen G.M. 869

Van Tieghem N. 559

van Vliet P.W. 675

Van Wezel A.L. 743

Vanderhaeghen J.J. 521

Vartio T. 303

Vassalli P. 71

Vaughan A.T.M. 937

Vennegoor C. 759,889

Verbanck P. 521

Verbist A. 543

Vercammen-Grandjean A. 559

Verhest A. 563

Versée V. 591

Verwey H. 129

Viau M. 373

Vidal H. 927

Vierendeels G. 521

Vincent C. 209, 777

von Gerstenberg A.C. 155, 793

von Grinsven H. 847

Vossen J.M. 667

Vray B. 493

Wacker A. 851

Wada T. 93

Waelbroeck M. 381, 509

Waks T. 903

Wang L. 817

warriner G.A. 89

Watson S. 477

Watt W.B. 125

Weigle W.0. 401

Wernet P. 805

Westbroek D.L. 243

Weston P.D. 751

Wiels J. 899

Wieslander A. 175

Wiklund B. 143

Wilkinson J.M. 187

Willems C. 609

Willems H.W. 701

Wilson B.S. 893

Wolf M. 267

Wood P.G. 283

Woodbury R.G. 877

Woodhouse C.S. 641, 921

Wroblewski H. 183

Wyatt R.T. 773
Yachi A. 93, 883, 893

Yacoub M.H. 691

Yamamura H.I. 487

Yamamura S.H. 487

Yao K. 15

Yeh C.-J.G. 451

Yeh M.-Y. 877

Young W.W. Jr. 809

Zahler P. 27, 267

Zaki L. 279

Zeeuws R. 591

Zeijlemaker W.P. 609, 723

Ziegler A. 805

Zuinghedau J . 159

zur Hausen H. 735

Zweibaum A. 595 



\section{SUBJECT INDEX}

Receptors and Membrane Proteins have been listed under their specific names.

Acetylcholine 599

Acetylcholinesterase 105, 109, 497

Acetylcholine receptor 497,781

A-chain 927

Acholeplasma laidlawii 15, 175, 251

Acid alpha-glucosidase 869

Acid secretion 599

ACTH 377

Actin 295

Activated $\mathrm{T}$ cells 729

Acute leukemia 623

ADCC 883

Adenovirus glycoprotein 97

Adenylate cyclase 381, 509, 531, 579

Adenylate cyclase inhibition 517

Adhesiveness 295

Adjuvant 401

Adrenal medulla 497

Affinity chromatography 591, 763

Ageing 325, 329, 333, 341

Agglutination 747

Airways - of the rat 501, 505

Alpha-adrenoceptor 505

Alpha-foetoprotein 369, 591

Alpha-glucosidase 869

Alpha,-microglobulin 777

Alpha -macroglobulin 427

Alpha-MSH $551,555,559,563$

Alpha-MSH receptivity 551, 563

Alpha-tissue antigen (alpha TA) 93

Amino acid sequence $41,57,187$, 237
Ampholyte displacement chromatography 955

Analytical zonal centrifugation 649

Angiotensin receptors 517

Animal 'immunoglobulins' 789

Anion transport 275

Anion transport and arginine specific reagents 279

Anion-transport protein 113

Anti-beta, M-goat serum 201

Anti $\mathrm{Na}$ (sodium) 255

Antibodies to cell surface 291

Antibody binding test 759

Antibody detection 627

Antibody fixation 159

Antibody fragments 419

Antibody heterogeneity 649

Antibody response 671

Anti CEA 641, 921

Antigen density 883

Antigens - surface 247

Antigen specific factor 671

Antigenic architecture 251

Antigenic cross-reactivity of TPA 143

Anti-glucocorticoid 393

Anti-HCG 817

Anti hIgG 817

Anti-idiotypes 563

Anti-5'nucleotidase serum 147

Anti-receptor antibodies 419

Anti-RHD antibodies 609 
Antiserum against C3R 435

Anti-T4 817

Aplastic anemia 667

Arylisothiocyanates 27

Associative recognition

231

Astatine 937

ATP depletion 109

Attachment factors 287

Auto-antibody 325, 365

Autoradiography 911

Bacterial membrane receptors

603

Bands 1 and 2 protein 121

Band 3 protein 113, 117, 275, 279

Basal-lateral membranes 139

Basement membrane collagen 773

Benzodiazepine 487

Beta-adrenergic binding sites 167

Beta adrenergic catecholamine receptors 493

Beta adrenergic receptor 163

Beta adrenoceptor 501, 505

Beta, adrenoceptor 505

17 beta carboxamide steroid 393

Beta-galactosidase 751

Beta IH-receptors 443

Beta,-microglobulin 187, 191, 195, 201, 205, 209, 243

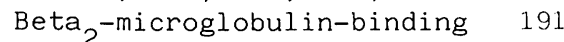

Beta-thromboglobulin 865

Biexponential dissociation kinetics 539

Bile acids 271

Biosynthetic hGH 833

Biotin-avidin 809

Blood group human - $\mathrm{M}$ and $\mathrm{N}$ specificities in guinea pig 213

Blood group human $\mathrm{M}-, \mathrm{N}-, \mathrm{T}-, \mathrm{TN}_{-}$ specificities in extracts of $\mathrm{L}-10$ carcinoma 213

Bloodgroups 49,57

Blood platelets 723

Bone marrow transplantation 667

Boyden chamber 201

Brain specific proteins 151.

Brucellosis 683

Brush border 271

Brush border vesicles 139

Burkitt's lymphoma 739

C-mu gene 37

C-delta gene 37

$\mathrm{CA}^{2+}$-dependent complexes 85

CA-induced $\mathrm{K}$ leak 283

C ALL antigen 227
Capping 405

Carbohydrate determinants 623

Carbohydrate receptors 389

Carcinoma associated Thomsen-Friedenreich ( $\mathrm{T})$ specificity 213

Carcinoembryonic antigen 93, 641 , $907,911,933$

Cardiac transplant 691

Cathepsins 397

CEA see carcinoembryonic antigen

CEA-like protein 195

Cell adhesion 291

Cell fusion efficiency 645

Cell mediated cytotoxicity 231

Cell sorter 675

Cell surface components 313,345

Cellular transformation 303

Central nervous system 521

c GMP 333

Chemiluninescence immunoassay

Chemotaxis 201

Chick brain 151

Cholate extract 263

Cholecystokinin 521

Cholera toxin 755

Chorionic somatomammotropin 855

Chromatofocussing 777, 955

Chronic lymphocytic leukemia 915

CL 2L8, 872487

Class switch $\quad 37$

Cold agglutinins 619,623

Cold agglutinin disease 365

Colloidal gold 943

Competition curves 555

Complement ( 1 , C2, C4) 317

Complement $\mathrm{C}_{1} \quad 439$

Complement degendent lysis 883

Complement (C3) receptors (C3R) 435

Complement receptors 443

Concanavalin-A receptor 147

Conditioned media 631

$\mathrm{C}_{3}$ receptors 443

Creatine kinase BB isoenzyme 873

Crossed immunoelectrophoresis 183 , 251

Crosslinking 27

Cross reactions 191

Cross reactivity 789

Crystallographic analyses 171

Cyclic adenosine monophosphate 571

Cyclic AMP 513, 579

Cyclic nucleotides 575

Cytochrome $\mathrm{C}_{1} 259$

Cytophiiic IgG 405

Cytoskeletal proteins 287

Cytotoxicity 937 
Daunomycin 933

Density dependent growth control 307

Detergents 15, 105, 171, 183

D-glucose transport 263

Differentiation $67,345,451$, 559,659

Differentiation antigens 813

Differentiation by specific antibody 743

Differentiation markers 805

Dimethyl disulphide 125

Dithioerythritol 263

o, o'-dityrosine 129

DLA 243

DNA sequence 41

Dopamine agonist 471

Dopamine antagonist 471

Dopamine receptor binding 471

Down regulation of receptors 539

Drug targeting 933

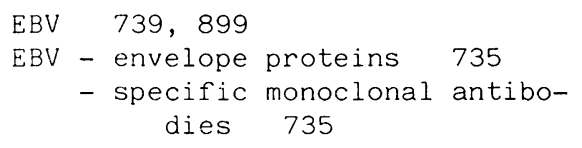

Electron diffraction 171

Electron microscopy 171

Electrophoresis 911

Eledoisin 477

Elisa $637,641,773$

Embryo 345

Endocytosis 459

Endothelial cells 609

Enterohepatic circulation 271

Enzyme immunoassay 837, 847

Epithelial cells 595

Epithelium 513

Epitope conservation 789

Epstein-Barr virus see EBV

Erythrocyte aging 337

Erythrocyte membrane reconstitution 105

Erythrocyte membranes 109, 113, $117,121,337,365,471$

Erythrocytes 15, 125, 275, 279

Escherichia coli 603

Estrogen binding 591

Estrogens 369

Evolution 191

Exchange 205

Extracellular matrix 307

Extraneural receptors 483

Facs
Fc fragments 401

FC receptor 439

FC gamma receptor 409

Fe receptors 385

Female genital tract 527

Feminizing factor 587

Fibroblasts 459

Fibronectin 291, 299

Fibronectin degradation products 303

Flow microfluorometry 687

Fluorescence activated cell sorter 687

Fluorometry 679

Focal contacts 287

Forssman-like antigen 159

Free flow electrophoresis 139

Friend cell 67

Gangliosides 797

Gangliotriosylceramide 809

Gardos effect 283

Gastric mucosa 599

Gastrin 599

Glucocorticoid 567

Glucocorticoid receptor 393, 583

Glycocalicin 359

Glycogen 595

Glycophorin 49

Glycoprotein 205 KD 435

Glycoproteins $57,67,71,89$, $221,325,365,659$

Glycosphingolipids 801, 805

Gonadotropins 567

Gram-neg. bacteria 317

Granulocytes 295

Graves'disease 571

Gross Virus leukaemia 231

Group N antigen anti-asialoganglioside 217

Growth 595

Growth factors 307

Growth hormone 827

Growth phases : horizontal and vertical 551

Growth regulation 307

GTP 513

Guanine nucleotides 381

Guinea pig L-10 hepatocarcinoma

213

Gut 513,595

$\mathrm{H}_{2}$ restriction 231

Hãemophilus influenzae 501

Hairy-cell leukaemia 75

Hamster 159 
Haptoglobin 397

HCG 837

$\mathrm{H}_{2}$ DIDS 275

$H^{2}-D I-h y d r o-A l$ prenolol

Heart 381, 531

Heavy chain C-region genes 37

Heinz body anaemia 125

Hemagglutinin 321

Heme hemopexin 463

Heme receptor 467

Hemin 467

Hepatocyte membrane binding 547

Hepatocytes $313,389,419,423$, $455,463,535$

Hexose uptake 345

High-affinity autoantibody

Histamine 599

Histocompatibility $\quad 187$

Histocompatibility antigens 205, 209, 221, 237

Histrionicotoxin 351

HLA - A, B, C 709

HLA antigens 723

HLA-D 729

HLA-DR 227, 713, 729

Homozygous typing cells 729

Hormone immunoassay 855

Hormone receptors 509

Hormone regulation 575

Human biosynthetic insulin 547

Human chorionic gonadotropin (HCG) 843

Human endothelial culture supernatant (HECS) 609

Human erythrocyte ghosts 267

Human erythrocyte membrane 263

Human growth hormones 833

Human growth hormones subfractions 587

Human hematopoietic cell lines 805

Human IgD 37

Human kidney 139, 773

Human liver cells 341

Human lymphocytes 409

Human melanoma associated antigen (High Molecular Weight) 893

Human melanoma cells 555, 559, 883

Human melanomas 559, 563, 877, 927

Human mouse hybridoma cells 609

Human prolactin 851,855

Human renal adenocarcinoma 903

Human superficial spreading melanoma 551

Human-T-lymphocytes 405

Human trials 915

Hyaluronic acid 341
Hybridoma $247,615,627,809$, $855,899,921$

Hybridoma antibody 907

Hybridoma growth pattern 627,645

Hybridoma technology 631

Hydrophobic chromatography 15 , 359

Hydrophobic constant domain 45

Hydrophobic interactions 105

Hypocholesterolaemia 125

Hypophysis 521

IA antigens 719
IgA receptor 419
Ig D 45
Ig FC portion 401
IgG 809
IgG immune complexes 649
Ig M 45,809
Immune surveillance 231
Immunochemical characterization
of TPA 143
Immunocytochemistry 943
Immunocytochemistry autoradiography
555

Immunodiagnosis $\quad 877$

Immunofluorescence 773

Immunoglobulin quantitation 785

Immunoglobulin receptors 431

Immunoglobulins 41,789

Immunogold staining 943, 949

Immunohistochemical-autoradiographic visualization 547

Immunohistochemistry 889

Immunohistology 773

Immunological monitoring 691

Immunoperoxidase technique 723

Immunoprecipitation 155, 735, 793

Immunoregulation 671

Immunoregulatory drugs

683

Immunotherapy 877

Immunotoxins 927

Infectious mononucleosis

739

Infertility 195

Influenza virus-induced fusion

Inhibition binding assays 893

Inside-out vesicles 267

Insulin 595

Insulin metabolism 543

Insulin porcine 547

Insulin receptors 535

Interferon 763

Interferon treatment 883

Internalization 547

Interspecies crossreactivity 255 
Intestinal transport 271

Intrinsic factor receptor

In vitro stimulation 609

In vitro translation 97

In vivo growth 645

In vivo scintigraphic studies

Ion channel 351

Ion pair 15

Iron 459, 467

Iron uptake 455

Isoelectric point 955

Isolated cells 599

K-ATPase antibodies

255

$\mathrm{K}^{+}$fluxes 329

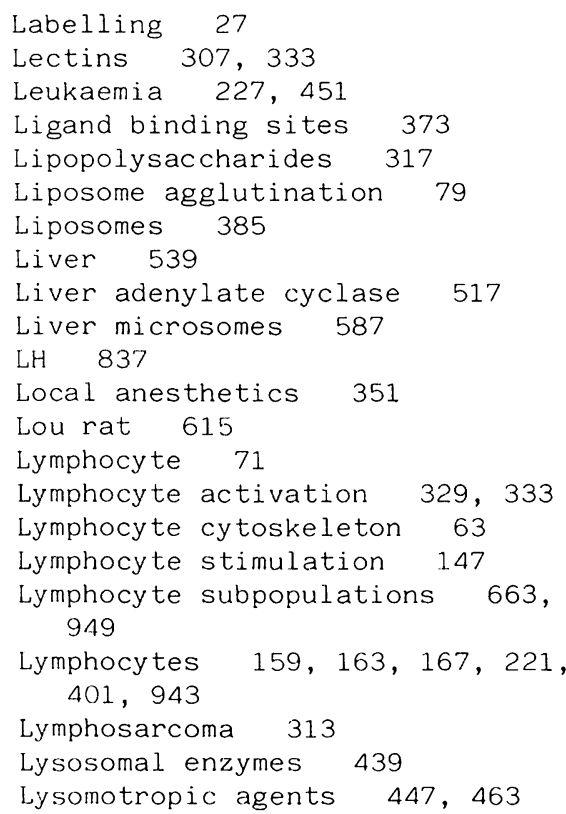

\section{Macro $\mathrm{CK}-\mathrm{BB} \quad 873$}

Macrophages 389,431

Major histocompatibility 231

Major histocompatibility complex 729

Mammary glands 813

$M^{C}$ antigen 57

Melanoma 889,915

Membrane antigens $71,155,679$, 793

Membrane associated tissular autoantigen (MTA) 93

Membrane asymmetry 251

Membrane fusion 267
Membrane glycoproteins 93, 337

Membrane lysis 603

Membrane molecule 237

Membrane protein clusters 337

Membrane protein biosynthesis 221

Membrane protein solubilization 171

Membrane proteins $15,27,89,133$ 317

Membrane reconstitution 79

Membranes 175

Messenger RNA 97

MHC 243

Microbial adherence 603

Microscopy - light 949

- light and elec-

tron 943

Milkfat globules 813

Mitochondria 259

Mitogenic lectins 147

Mixed lymphocyte reactions 695 , 719

MNSS system 471

Molecular heterogeneity 893

Molecular weight of C3R 435

Monoclonal antibodies to human IgG 649

Monoclonal antibodies to estrogens 823

Monoclonal antibodies to human leukocyte interferons 763

Monoclonal antibodies 33, 227 , $365,427,615,619,637,641$, $653,659,663,667,671,675$, $679,687,691,695,701,705$, $709,719,729,737,743,747$, $751,755,759,769,773,777$, $781,789,793,797,801,813$, $827,833,837,843,847,851$, $855,865,869,877,883,889$, 893, 903, 911, 927, 933, 943, 949

Monoclonal anti-HLA antibodies 723

Monoclonal autoantibodies 861

Monoclonal human antibodies 623

Monocytes 201

Monomer/dimer/tetramer association equilibrium 117

Mouse hybridoma 801

$\mathrm{M}^{\mathrm{g}}$ antigen 57

Multiple sclerosis 965

Multiwire proportional counter 961

Murine monoclonal antibodies 915

Murine $\mathrm{T}$ cell clones 133

Muscarinic receptors 381

Mutational hypothesis of Clark 551

Myasthenia gravis 781

Mycoplasma identification 759

Myeloma cells 645 
Myometrium

$\mathrm{N}$-acetyl neuraminic acid 619

$\mathrm{Na}^{+}, \mathrm{K}^{+}$ATPase 139, 329

Natural killer activity 653

Natural killer cell heterogeneity 663

Negative cooperative interactions 539

Neo antigenic determinants

427

Neutral glycosphingolipids

797

Neural receptors 483

Neuraminidase 321, 619

Neuraminidase-resistant 75

Neuron 247

Neuropeptides 521, 535

Neurotensin-receptor interactions 483

Neutralization test 559

Non-esterified fatty acids

Nuclear magnetic resonance

369

5'Nucleotidase 33,147

Ozone

129

Para influenza-3-virus 101

Paramyxovirus - induced fusion 321

Pathological immunoglobulins 571 ,

PBE 575

Peptide hormones 477, 535

Peritoneal macrophages 439

Phagocytosis 295

Pharmalyte $\mathrm{R}^{\mathrm{S}} 955$

Phencyllidine 351

Phosphodiesterase 513

Phospholipase $A_{2} \quad 267$

Phospholipid liposome 263

Phospholipid monolayers 121

Phospholipid spectrin interactions 121

Phospholipids 105

Photoaffinity labelling 351

Physalaemin 477

Pigmented and unpigmented melanocytes 563

Pituitary protein hormones

855

Plasma hormone levels 567

Plasma membrane 33

Plasma membrane proteins 291

Plasminogen activator 299

Platelet aggregation 85

Platelet glycoprotein 79

Platelet membrane glycoprotein IB 359
Platelet membrane glycoproteins II and IIIa 85

Poliomyelitis virus 743

Polybuffer TM 955

Polyclonal antibody 769

Polymeric IgA 423

Polypeptides 18 and 38 KD 435

Pompe's disease 869

Portal route infusion 547

Post gamma globulin 769

Pre- and postmenopausal women 567

PR-antigens 365

Precursor cells 937

Prolactin liver receptors 587

Pregnancy 837

Preparative agarose-suspension electrophoresis 183

Prolactin 567, 847

Prostatic acid phosphatase 865

Proteases 259, 397

Protease inhibitors 397

Protein A $\left(I_{125}\right) \quad 159$

Protein acylation 113

Protein cross-linking 129

Protein fractionation 155, 955

Protein-lipid interactions 175

Protein micelles 101

Protein processing and transport 259

Protein synthesis 377

Proteolytic enzymes 471

Purple membrane 183

Rabies virus 743

Rabbit 679

Rabbit B and T lymphocytes 687

Radiochemical analysis 187

Radioiodination 179

Radioimmunoassay 769,873

Radiolabelling 237

Radiosequence of proteins 97

Rat 501, 615, 705

Rat cerebral cortex 535

Rat serum glycoprotein 209

Ratio beta /beta, receptors 167

RCAI lectin binding 341

Receptivity 563

Receptor binding 487

Receptor for heme 467

Receptor for polyanions 439

Receptor inhibition 471

Receptor intrinsic factor 385

Receptor-mediated endocytosis 389 , $427,447,463$

Receptors 477, 513, 595, 599

Receptors for regulatory peptides 595 
Recycling 447

Rejection 691

Relation structure function

377

Resealed ghost 283

Retroviral markers 559

RIA 637

Ricin 927

RNA oncogenic viruses

SA antigen 365

Sandwich immunoassay for interferon 763

Sandwich test 865

Schistosoma mansoni

Schistosomula 179

179

Screening procedures

Secretin 509, 513

Secretory component 419

Secretory vesicles 497

Selection 627

Self association 117

Semen 195

Seminal plasma 195

Separation techniques 175

Sequential immunodepletion

893

Serum bactericidal effect

317

Serum DBP 373

Serum protein binding 961

Sex steroids 567

Sheep erythrocyte membranes

267

Sheep red cells 671

Sialic acid $57,75,365$

Sialoglycoprotein 49

Smooth muscle control 527

Sodium dodecyl sulfate - poly-acrylamide gradient electrophoresis 183

Sodium Dodecyl sulphate polyacrylamide slab gel 911

Soft agar cloning 627, 645

Soluble actin fraction 373

Soluble immune complexes 431

Specific actin binding 373

Specific binding demonstration 543

Specific binding sites 527, 535, 539

Specific drug carriers 389

Spectrin 121, 129

Spectrin-phospholipid interaction 127

Spectroscopy 467

Spermatozoa 195

Spontaneously hypertensive (SHR) rats 531

Ss antigens 57

Stereospecificity 263

Steroid hormones 823

Streptococcal group A 797
Streptococcal grouping 747

Structure-activity-relationships

Structure-activity studies 483

Subacute sclerosing panencephalitis 965

Subsets 713

Substance P 477

Subtypes 743

Subunite interaction 755

Subunit vaccine 101

Suppression 671

Suppressor cells 683

Suppressor factor 409

Suppressor/cytotoxic cells 653

Suppressor T cells 663

Surface antigens 179, 247

Surface glycopeptides 75

Surface glycoproteins 63

SV $40 \quad 159$

Synaptic plasma membrane 151

Synaptosomes 535

Syncytium forming units 559

Synergism 751

Synthetic neurotensin analogues

$T_{3} \quad 817$

Targeting 921

$T$ cell differentiation 675

T cell hybrid 671

T cell subsets 667

$\mathrm{T}$ cells 683, 705, 729

T cells cytotoxic 663

Ternary complexation 283

Tetanus toxin 247

Theory of immune complex formation 649

Thymocytes $679,701,705$

Thyroglobulin 861

Thyroid 579

Tissue distribution 777

T lymphocytes 653, 659, 701

T-1ymphocyte subsets 691

Torpedo electric organ 155, 793

TPA 143

Transcellular transport of IgA 423

Transfer electrophoresis 965

Transferrin 459

Transferrin iron 447

Transferrin receptor 227, 451, 455

Transformation 299, 451

Transformation antigen 739

Transformation enhancing factors 303

Transformed lymphocytes 739

Transmembrane interaction 287

Transmembrane linkages 63 
Triazolopyridazine

487

Tritium 961

Trophoblast 89

Tryptic peptide mapping

TSH receptor 571,575

Tumor antigen 899, 903

Tumor associated antigens 877,889

Tumor cells 159

Tumor serology 877

Tunicamycin 67

Twodimensional immunoelectrophoresis 961

Ultrathin frozen sections

773

Univalent antibodies

313

Uterus 369

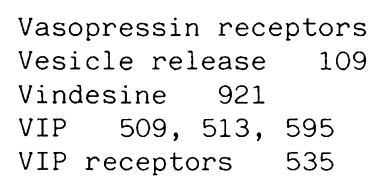

